\title{
Interest rate pass-through in the Dominican Republic
}

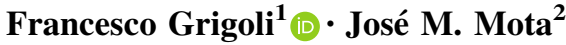

Received: 29 June 2016/Revised: 15 March 2017/Accepted: 17 March 2017/

Published online: 5 April 2017

(C) The Author(s) 2017. This article is an open access publication

\begin{abstract}
A well-functioning monetary transmission mechanism is critical for monetary policy. As the Dominican Republic recently adopted an inflation targeting regime, it is even more relevant to guarantee that changes in the monetary policy rates are quickly and fully reflected in retail rates, to eventually influence aggregate demand and inflation. This paper estimates the interest rate pass-through of the monetary policy rate to retail rates and explores asymmetries in the adjustment. We find evidence of complete pass-through to retail rates, confirming the effectiveness of the monetary policy transmission mechanism. However, our results also suggest a faster pass-through to lending rates than to deposit rates and asymmetric adjustments of short-term rates, as deposit rates respond faster to policy rate cuts and lending rates respond faster to policy rate hikes. Measures to enhance competition in the financial system could help to achieve a symmetric adjustment of retail rates.
\end{abstract}

The views expressed in this paper are those of the author(s) and do not necessarily represent the views of the International Monetary Fund (IMF), its Executive Board, the IMF management, or the Superintendency of Banks of the Dominican Republic. We thank Svetlana Cerovic, Przemek Gajdeczka, Metodij Hadzi-Vaskov, Hibiki Ichiue, Raul Ovalle, Evelio Paredes, Pau Rabanal, Andrew Swiston, Apolinar Veloz, and an anonymous referee for helpful comments and suggestions. We are also grateful for the suggestions made by participants in the seminars of the Western Hemisphere Department of the IMF, the Superintendecy of Banks of the Dominican Republic, and the Ministry of Finance of the Dominican Republic, all held in November 2015.

Francesco Grigoli

fgrigoli@imf.org

José M. Mota

jmota@sb.gob.do

1 International Monetary Fund, Washington, USA

2 Superintendency of Banks of the Dominican Republic, Santo Domingo, Dominican Republic 
Keywords Asymmetric · Dominican Republic · Interest rate pass-through · Transmission mechanism

\section{JEL classification numbers E43 $\cdot$ E52}

\section{Introduction}

The global slowdown and recent price developments renewed the interest in evaluating the effectiveness of monetary policy. It is widely acknowledged that an effective monetary policy relies on a well-functioning transmission mechanism. If changes in monetary policy rates are quickly and fully transmitted to retail rates, the latter have a faster impact on domestic demand and therefore inflation (Mishkin 1995; Becker et al. 2012). Conversely, if retail rates are sticky, the monetary policy goals take longer and are harder to achieve. As the Dominican Republic recently adopted an inflation targeting regime, it is even more relevant to ensure that changes in the monetary policy rates are quickly and fully reflected in retail rates to eventually affect inflation.

The theoretical literature advanced several possible explanations as to why the interest rate pass-through may be slow, incomplete, more than complete, or asymmetric. These include asymmetric information, menu costs, switching costs, risk sharing, ownership of the financial system, economic conditions, and bank concentration. While the empirical literature for advanced and emerging economies is vast, the evidence for the Dominican Republic remains limited.

In this paper, we estimate the interest rate pass-through for retail rates in the Dominican Republic. The contribution to the existing literature is twofold. First, we provide a wide spectrum of results for retail rates at different maturities and for a recent period, with some analysis of the fiscal costs (i.e., public sector borrowing costs) associated with monetary policy. Second, we test for asymmetries in the adjustment to equilibrium and simulate the symmetric and asymmetric adjustment of retail rates to changes in the monetary policy rate.

We find evidence of complete pass-through to retail rates, confirming the effectiveness of the monetary policy transmission mechanism. Similarly, our results indicate that government domestic bond yields increase when monetary policy becomes more contractionary. However, we also find evidence of a faster passthrough to lending rates than to deposit rates. Moreover, short-term deposit rates respond faster to policy rate cuts with respect to hikes, while short-term lending rates respond faster to policy rate hikes with respect to cuts. The theoretical literature associates asymmetries in the speed of adjustment to collusive market behaviors. Thus, measures to boost competition in the financial system could help to achieve a symmetric adjustment of retail rates.

The paper is organized as follows. Section II reviews the theoretical contributions explaining rigidities and asymmetries in the interest rate pass-through, comments on the institutional features of the financial system of the Dominican Republic, and discusses the empirical evidence for the country. Section III presents the empirical strategy. Section IV discusses the results. Section V concludes. 


\section{The pass-through in the Dominican Republic}

In this section, we briefly review the main theoretical reasons for which retail rates may show stickiness or asymmetries when the monetary policy changes. Then, we describe the institutional framework of the Dominican banking system and review the existing empirical literature on the interest rate pass-through for the Dominican Republic.

\subsection{Theoretical contributions}

Stiglitz and Weiss (1981) relate stickiness to asymmetric information. When banks perceive the default risk to be high, they are inclined to maintain a large spread between lending and deposit rates. However, given that borrowers that accept higher rates are likely to be of poor quality and borrowers with less risky investments are likely not to borrow if rates increase (i.e., adverse selection), and given that any increase of lending rates will give incentives for borrowers to choose riskier projects (i.e., moral hazard), any monetary policy rate increase would raise the probability of loan default. Thus, banks may decide not to raise their rates albeit their cost for getting funds increases, and reach the equilibrium in the loan market by rationing credit. As a result, lending rates may be rigid upwards and adjustment may turn out to be asymmetric.

Bernanke et al. (1996) show that financial frictions may cause large fluctuations in economic activity, and consequently in retail rates. In the presence of asymmetric information, lenders may require borrowers to collateralize their assets. In response to a monetary policy rate hike, for example, the balance sheets of firms deteriorate owing to the fall in asset prices. As a result, firms have less ability to borrow, which ultimately affects investment. This starts a vicious cycle (i.e., financial accelerator) where lower economic activity dampens asset prices, which further tightens financing conditions and reduces economic activity. This mechanism may induce overpass-through from the monetary policy rate to the retail rates. ${ }^{1}$

De Bondt (2005) uncovers another reason for which asymmetric information leads to overpass-through. Banks may react to risks involved in asymmetric information by raising interest rates beyond the size of the increase in the policy dictated rate, instead of rationing credit. In other words, lending rates must increase by an amount greater than the increase in the monetary policy rate to compensate for the decrease in the probability of repayment. However, there is a limit to this. Beyond some interest rate level, banks will not be able to increase the interest rate sufficiently to compensate for this risk and all lending will be made to the less risky borrowers. However, until this happens, the bank rate on these loans should be very sensitive to changes in the market interest rate.

Rotemberg and Saloner (1987) explain price rigidity by formulating the menu costs theory. This predicts that firms will change their prices only when the benefits from doing this are greater than the costs of changing prices (e.g., printing, advertising new price lists, communicating to customers, etc.). Hence, if the

\footnotetext{
${ }^{1}$ See also Gertler and Karadi (2011) and Gerali et al. (2010).
} 
monetary policy rate change is perceived as small and temporary, and the costs associated to changing retail rates are higher than the benefits, banks may opt to delay the retail rate changes. ${ }^{2}$

Lowe and Rohling (1992) argue that switching costs can cause retail rates rigidity. Banks incur costs to collect information about the risk profile and behaviors of their customers and these are generally passed on to them as one-off fees. If costs associated to switching to a different bank are high enough, customers may decide to accept a more penalizing interest rate by their current bank instead of incurring these costs. Thus, higher switching costs may imply stickiness of retail rates as well as asymmetric adjustment.

Fried and Howitt (1980) show that banks and customers are better off by sharing risk and this increases retail rates rigidity. More specifically, as movements in interest rates affect banks' and customers' earnings, banks could offer an equilibrium risk-sharing agreement (e.g., an insurance contract) for which banks agree to compensate customers in case of unfavorable interest rate movements against the payment of a fee. Customers would then hesitate to change banks because of this agreement. Similarly, Berger and Udell (1992) highlight the role played by implicit contracts for which banks interested in long-term relationships are willing to offer more stable interest rates. All these kinds of agreements result in stickier retail rates.

The ownership structure of the financial system also plays a role in shaping the transmission mechanism of monetary policy. State-owned financial institutions are often the key in achieving policy objectives of governments, and as a result maximizing profit is not their primary aim. In this context, interest rates are likely to adjust with a delay due to inefficiencies and political considerations, hence causing stickiness in interest rate adjustment.

Égert et al. (2007) and Égert and Macdonald (2009)highlight the role of macroeconomic conditions in affecting retail rates stickiness. If volatility is high, the information content of policy signals is reduced as noise increases. Consequently, banks would wait more to change their rates. Moreover, the pass-through is likely to be faster during high inflation periods as prices are adjusted more frequently. High economic growth also favors a quicker pass-through as banks find it easier to pass on changes when conditions are favorable.

The interest rate pass-through may be asymmetric because bank concentration leads to oligopolistic behaviors. On one hand, the collusive behavior hypothesis of Hannan and Berger (1991) suggests that following an increase in the monetary policy rate, deposit rates could be rigid upwards because higher deposit rates represent an additional cost for banks. Similarly, the lending rates could exhibit downward rigidity in reaction to a reduction in the monetary policy rate as lower lending rates imply lower profits for banks. On the other hand, the adverse customer reaction hypothesis indicates that if customers have bargaining power deposit rates

\footnotetext{
${ }^{2}$ De Bondt (2002) and De Bondt et al. (2003) further analyze the role of expectations of future interest rates, explaining that the current change in retail rates also depends on the extent to which the monetary policy rate change has been anticipated and how it changes future rates.
} 
could be rigid downwards when the monetary policy rate falls and lending rates may be rigid upwards when the monetary policy rate increases.

\subsection{Characteristics of the Dominican financial system and empirical evidence}

The recent history of the Dominican Republic's monetary policy starts with the Monetary and Financial Law of 2002. The law strengthened the institutional framework for the conduct of monetary policy by establishing price stability as the main central bank's mandate. Starting in 2004, the central bank moved away from exchange rate targeting and transitioned to monetary targeting. In this context, it introduced an overnight deposit window and a Lombard facility, which created a corridor for the interbank rate. The overnight rate served as signal of the monetary policy stance.

The monetary targeting anticipated the transition to the inflation targeting regime. While the central bank managed to significantly reduce inflation and stabilize the economy under the monetary targeting, financial innovation and deregulation as well as financial sector reforms generated a growing instability in money demand, weakening the relationship between money and inflation (Andújar 2014). To strengthen monetary policy effectiveness, the BCRD adopted an inflation targeting regime in January 2012. Starting in February 2013, the authorities introduced the monetary policy rate as the benchmark rate, which is in the middle of a corridor bounded by the one-day deposit and expansion facilities.

Since the financial crisis of 2003-04, the financial system developed considerably but remains highly concentrated. As of June 2015, the system is composed of 65 financial entities with assets over $45 \%$ of GDP and a loan portfolio of $27 \%$ of GDP. ${ }^{3,4}$ Most of the loans go to the commercial sector $(58.7 \%)$, while the remainder is split between personal consumption loans (24\%) and mortgage loans (17.3\%). Commercial and mortgage loans are usually backed by a collateral, which contributes to lower the interest rate. In June 2006, the three main banks used to represent $57.5 \%$ of deposits and 58.2\% of loans, while as of June 2015 they represent $67.7 \%$ of deposits and $69.0 \%$ of loans.

As discussed, the degree of concentration is often associated with collusive behavior. This generally translates into high profits for banks as well as asymmetries in the adjustment of retail rates to the monetary policy rates. In the Dominican Republic, spreads are high at all maturities $(6.5 \%$ on average for 3-month spread over 2006-2015) and vary significantly when the monetary policy rate changes. ${ }^{5}$ This suggests that deposit and lending rates may either react differently to changes in the monetary policy rate, react asymmetrically to lifts and cuts in the monetary policy rate, or both.

\footnotetext{
${ }^{3}$ Ratios to GDP are calculated using the 2014 nominal GDP.

4 The financial system consists of 17 commercial banks (85.8\% of the system assets), 10 saving and credit institutions (11.1\% of the system assets), 19 credit unions (1.9\% of the system assets), several credit corporations ( $0.3 \%$ of the system assets), and a development bank ( $0.9 \%$ of the system assets).

5 While this is true for spreads at all maturities, we present only the 3-month spread in the chart for space reasons.
} 
Table 1 summarizes the findings of the empirical literature on interest rate passthrough for the Dominican Republic. Sample size, interest rate variables, model specifications, and estimation methodologies vary significantly across studies. Most of the literature finds evidence of overpass-through to lending rates, albeit the results present a significant variation in the estimated pass-through. As for the deposit rates, results are generally mixed, with estimates ranging from incomplete to overpass-trough.

González Pantaleón (2010) finds over pass-through of the interbank rate to both lending and deposit rates. He employs an error correction model (ECM) to estimate a specification that includes several explanatory variables. He finds that the Emerging Market Bond Index (EMBI) spread, the reserve requirement coefficient, and the Lombard window rate are significantly associated to increases in retail rates.

Rivas (2011) is the first to explore asymmetries in the interest rate pass-through for the Dominican Republic. With an asymmetric ECM applied to a parsimonious specification that includes only the interbank rate, he studies the adjustment of the retail rates to positive or negative changes in the monetary policy rate. He finds

Table 1 Literature for the Dominican Republic

\begin{tabular}{|c|c|c|c|c|}
\hline Author & $\begin{array}{l}\text { Empirical } \\
\text { approach }\end{array}$ & Sample period & $\begin{array}{l}\text { Estimated long-run } \\
\text { coefficient }\end{array}$ & Explanatory variables \\
\hline $\begin{array}{l}\text { Gonzalez } \\
\text { Pantaleon } \\
(2010)\end{array}$ & ECM & $\begin{array}{l}\text { Quarterly data } \\
\text { (1996Q1-2010Q1) } \\
\text { and monthly data } \\
\text { (1996M1-2010M4), } \\
\text { excluding 2003 and } \\
2004\end{array}$ & $\begin{array}{l}\text { Loans: } 0.96-1.44, \\
\text { Deposits: } \\
0.91-1.23 \text {, } \\
\text { Commercial loans: } \\
\text { 1.04-1.25, Personal } \\
\text { cons, loans: } \\
\text { 0.96-1.13, } \\
\text { Mortgage loans: } \\
\text { 1.15-1.45 }\end{array}$ & $\begin{array}{l}\text { Interbank rate, } \\
\text { external interest } \\
\text { rate, EMBI spread, } \\
\text { reserve requirement } \\
\text { coefficient, } \\
\text { Lombard window } \\
\text { rate }\end{array}$ \\
\hline Rivas (2011) & $\begin{array}{l}\text { Asymmetric } \\
\text { ECM }\end{array}$ & $\begin{array}{l}\text { Monthly data } \\
(1996 \mathrm{M} 1-2011 \mathrm{M} 8)\end{array}$ & $\begin{array}{l}\text { Loans: } 0.90-1.42 \\
\text { Deposits: } 1.00\end{array}$ & Interbank rate \\
\hline $\begin{array}{l}\text { Medina, } \\
\text { Carrion, and } \\
\text { Frantischek } \\
(2011)\end{array}$ & $\begin{array}{l}\text { Panel } \\
\text { S-GMM }\end{array}$ & $\begin{array}{l}\text { Annual data (2004-10) } \\
\text { for } 40 \text { countries }\end{array}$ & Loans (DR): 0.65 & $\begin{array}{l}\text { Monetary policy rate, } \\
\text { financial } \\
\text { dollarization, } \\
\text { exchange rate } \\
\text { flexibility, size of } \\
\text { the banking sector, } \\
\text { banking } \\
\text { concentration, and } \\
\text { interactions }\end{array}$ \\
\hline $\begin{array}{r}\text { Andujar } \\
(2012)\end{array}$ & ECM & $\begin{array}{l}\text { Monthly data } \\
\text { (1996M1-2007M12) }\end{array}$ & $\begin{array}{l}\text { Loans: } 0.94 \text {, } \\
\text { Deposits: } 0.73-0.77\end{array}$ & Interbank rate \\
\hline $\begin{array}{l}\text { Aristy } \\
\text { Escuder } \\
(2014)\end{array}$ & ADL model & $\begin{array}{l}\text { Monthly data } \\
\text { (2008M1-2014M8) }\end{array}$ & $\begin{array}{l}\text { Loans: } 2.66, \\
\text { Deposits: } 1.65\end{array}$ & $\begin{array}{l}\text { Monetary policy rate } \\
\text { (overnight) }\end{array}$ \\
\hline BCRD (2015) & N/A & N/A & $\begin{array}{l}\text { Loans: } 1.06-1.63 \text {, } \\
\text { Deposits: } 0.85-0.92\end{array}$ & \\
\hline
\end{tabular}

The estimated long-run coefficient refers to different maturities depending on the paper 
overpass-through for the 6-month and 1-year lending rates and completes passthrough for the same maturity deposit rates. He also finds evidence of increased efficiency of monetary transmission mechanism in the post-crisis period compared to the pre-crisis one. Finally, he does not find any evidence of asymmetric adjustment.

Medina Cas et al. (2011) find a high degree of stickiness in the pass-through to deposit and lending rates. Using a 40-country panel data over the period 2004-2010, the authors estimate a dynamic specification with system generalized method of moments (S-GMM) that includes interaction terms between the monetary policy rate and a set of explanatory variables. The authors find that although the estimated pass-through for the Dominican Republic is incomplete owing to high dollarization and limited exchange rate flexibility, it is greater than for Central American countries.

By employing an ECM, Andújar (2012) finds a complete pass-through to lending rates and an incomplete one to deposit rates. Also, his results suggest that starting in 2005 the monetary transmission mechanism became more efficient and that changes in the interbank rate take from four to 5 months to be reflected in retail rates. Finally, using simulations the author shows that permanent changes in the policy rates are associated with a stronger reaction of retail rates compared to temporary changes.

Aristy Escuder (2014) finds evidence of overpass-through for both lending and deposit rates. More specifically, he estimates an autoregressive distributed lag (ADL) model with a parsimonious specification including only the overnight rate. His results suggest that the size of the overpass-through is much larger than in the existing literature.

Banco Central de la Republica Dominicana (2015) also finds overpass-through to the lending rates, but incomplete or complete pass-through to the deposit rates. While estimation details are not available, the study presents results for a wide range of interest rates and for the calculations of the speed of adjustment in months. This ranges between one and 2 months for all interest rates, with the exception of the 6-month lending rate, which adjusts in about 4 months.

\section{Empirical strategy}

Let $\mathrm{rr}_{t}$ denote the endogenously determined retail rate at time $t$ :

$$
\mathrm{rr}_{t}=\alpha+\beta_{1} \mathrm{mpr}_{t}+\beta_{2} X_{t}+u_{t},
$$

where $\alpha$ is an intercept which denotes a mark-up or mark-down on the retail rate to reflect market conditions, ${ }^{6} \mathrm{mpr}_{t}$ is the monetary policy rate, ${ }^{7} X_{t}$ includes a set of factors influencing the retail rate beyond the monetary policy rate, $\beta_{1}$ and $\beta_{2}$ are the

\footnotetext{
6 See Marotta (2009).

7 The monetary policy rate used in the regressions is a proxy of the average monetary policy rate for the month. Given that the decision to change or maintain the rate is taken during the last week of the month, we assume that the average for the current month is equal to the last month's value of the monetary policy rate.
} 
relative coefficients, and $u_{t}$ is a stochastic error term that captures unobserved heterogeneity. ${ }^{8}$

Departing from most papers in the literature, we employ a richer specification with the vector of exogenous covariates $X_{t}$ encompassing five variables. First, we add the reserve requirement coefficient for commercial bank deposits at the central bank in local currency as increases in the coefficient correspond to withdrawals of liquidity in the financial system, resulting in higher retail rates. Second, we also add nonperforming loans (NPLs) as a share of total loans with the aim of capturing increases (decreases) in the lending (deposit) rates that compensate higher banks' losses when NPLs increase. Third, we include the average exchange in the event retail rates adjust to maintain a stable pace of depreciation rather as a reaction to changes in the monetary policy rate. Fourth, we include the EMBI spread as a time-varying measure of the risk premium. And fifth, we add the Volatility Index (VIX) to reflect external market's volatility (especially advanced economies) expectation for the next 30 days. The expected effect of the VIX is ambiguous. When volatility in advanced economies is high, interest rates may drop as capital flies toward emerging markets such as the Dominican Republic, or may go up if volatility is perceived as a global issue and capital flies to quality. Finally, we add two dummy variables for regime changes. The first one is for the inflation targeting period and the second is for the period in which the monetary policy rate was introduced as a benchmark.

Our attention falls on the fraction of the change in monetary policy rate reflected in changes in retail rates over the long run. ${ }^{9}$ This is expressed by the parameter $\beta_{2}$, which is close to zero when the transmission mechanism is weak and takes value one when the pass-through is complete. As discussed, a bunch of factors may prevent the pass-through to be complete, and in some cases, $\beta_{1}$ could be higher than one, implying overpass-through.

With the purpose of having a wide glance at the financial system, we analyze the impact of changes in monetary policy on several retail rates with monthly data over the period June 2006-June 2015. In particular, $\mathrm{rr}_{t}$ is, alternatively, the deposit or lending rate at 90, 180, 360 days, the weighted average rate, as well as the commercial, personal consumption, and mortgage lending rate of commercial banks. ${ }^{10} \mathrm{Also}$, we explore the interest rate pass-through from the monetary policy rate to government domestic bond rates for instruments at 5, 7, and 10 years, as well as for 10-year government bonds issued in the sovereign market. However, since these kinds of instruments are not issued every month, we rely on the interest rate in the secondary market. Given the reduced sample size, results need to be taken with caution. ${ }^{11}$

\footnotetext{
8 A trend is excluded a priori because there is no theoretical reason for which interest rates should exhibit a deterministic time trend (see Hamilton 1994).

9 As we are interested in estimating the pass-through from themonetary policy rate-which is clearly exogenous - to retail rates, and to avoid relying on asymptotic properties of the maximum likelihood estimation, we opt for a single equation approach rather than a multivariate one.

${ }^{10}$ Due to data availability, we limit our analysis to commercial banks, which represent 85.8 percent of the financial system assets.

11 Observations start in May 2009 for the 5-year domestic bonds, February 2010 for the 7-year domestic bonds, August 2010 for the 10-year domestic bonds, and April 2010 for the 10-year sovereign bonds, and end in June 2015. However, the series contain some missing observations.
} 
The literature often finds that interest rate series are non-stationary. In the presence of unit roots, estimating Eq. (1) with ordinary least squares would result in spurious coefficients. Thus, we first test the levels and first differences of all series for unit root employing the Augmented Dickey Fuller (ADF) test. When the hypothesis of unit root cannot be rejected for the levels, we test for cointegration between the retail rates and the monetary policy rate using the Engle-Granger test.

In those groups of data for which cointegration are not found, we estimate the following ADL model:

$$
\Delta \mathrm{rr}_{t}=\eta+\gamma_{1} \Delta \operatorname{mpr}_{t}+\sum_{i=1}^{n} \gamma_{i} \Delta \mathrm{mpr}_{t-i}+\delta_{1} \Delta X_{t}+\sum_{k=1}^{m} \delta_{k} \Delta X_{t-k}+\sum_{j=1}^{p} \zeta_{j} \Delta \mathrm{rr}_{t-j}+\varepsilon_{t}
$$

where $\Delta$ is the difference operator, $\eta$ is the constant, $\gamma_{1}$ is the short-run pass-through (i.e., within the same month), $\delta_{k}$ are the coefficients for the changes in the variables of vector $X_{t}$ and their lags, $\zeta_{j}$ are the coefficients for the changes of the lags of the dependent variable, $n, m$, and $p$ are the maximum number of lags, and $\varepsilon_{t}$ is a white noise error term. The long-run pass-through coefficient $\beta_{1}$ can be retrieved as $\sum_{i=1}^{n} /\left(1-\sum_{j=1}^{p} \zeta_{j}\right)$.

For groups of data sharing a long-run relationship (i.e., cointegrated), Eq. (2) can be re-parameterized into an error correction model (ECM) that ties the short-run disequilibrium to the long-run equilibrium (Hendry and Nielsen 2007):

$$
\Delta \mathrm{rr}_{t}=\eta+\gamma_{1} \Delta \mathrm{mpr}_{t}+\sum_{i=1}^{n} \gamma_{i} \Delta \mathrm{mpr}_{t-i}+\delta_{1} \Delta X_{t}+\sum_{k=1}^{m} \delta_{k} \Delta X_{t-k}+\rho u_{t-1}+\varepsilon_{t},
$$

where $\rho$ is the percentage of the previous period deviation from to the long-run equilibrium $u_{t-1}$ that is corrected in every period $t$. In other words, it represents the speed at which bank rates adjust back to equilibrium after a change in the monetary policy rate. $^{12}$

Enders and Siklos (2001) show that the Engle-Granger cointegration test is misspecified if adjustment is asymmetric. In particular, they argue that it is a special case of the threshold autoregressive (TAR) model, which allows testing for asymmetric cointegration. The TAR model can be written as:

$$
\Delta u_{t}=I_{t} \rho_{1} u_{t-1}+\left(1-I_{t}\right) \rho_{2} u_{t-1}+\sum_{l=1}^{q} \gamma_{l} \Delta u_{t-l}+v_{t}
$$

where $I_{t}$ is the Heaviside indicator function such that:

\footnotetext{
12 The literature (see Doornik and Hendry 1994) also calculates the mean adjustment lag as $\left(1-\gamma_{1}\right) / \rho$, which reveals how many months it takes for the change in the monetary policy rate to be fully reflected in retail rates. This measure, however, assumes that there is complete pass-through (i.e., $\beta_{1}=1$, and that the portion of adjustment $\rho$ is the same every month (rather than being a percentage of previous year deviation from equilibrium).
} 


$$
I_{t}=\left\{\begin{array}{ll}
1, & u_{t-1} \geq \tau \\
0, & u_{t-1}<\tau
\end{array},\right.
$$

and $\rho_{1}$ and $\rho_{2}$ are the estimates if $u_{t-1}$ is above or below the threshold $\tau$, respectively. The value of $\tau$ is unknown and can be estimated using the method illustrated in Chan (1993). However, it can also be set a priori. In our case, we set it to zero and we also estimate it. Enders and Siklos (2001) propose the $\Phi$ and the t-max statistics to test for asymmetric cointegration. The $\Phi$ statistic is an $F$-statistic testing the null hypothesis that $\rho_{1}=\rho_{1}=0$, while the $t$-max is a $t$-statistic testing the null hypothesis with the largest $\rho_{\mathrm{i}}=0 .{ }^{13}$ Hence, if the null hypothesis of no cointegration is rejected, we can test the null hypothesis that $\rho_{1}=\rho_{2}$ by a standard $F$ statistic. A rejection of this hypothesis implies asymmetric adjustment.

Policymakers may be interested in reducing large changes in the retail rates. Enders and Granger (1998) and Carner and Hansen (1998) propose a variation of the TAR model of Eq. (4), known as momentum TAR (M-TAR) model:

$$
\Delta u_{t}=M_{t} \rho_{1} u_{t-1}+\left(1-M_{t}\right) \rho_{2} u_{t-1}+\sum_{l=1}^{q} \gamma_{l} \Delta u_{t-i}+v_{t},
$$

where $M_{t}$ is an alternative Heaviside indicator function to the one in Eq. (5) such that:

$$
M_{t}=\left\{\begin{array}{ll}
1, & \Delta u_{t-1} \geq \tau \\
0, & \Delta u_{t-1}<\tau
\end{array} .\right.
$$

As in the case of the TAR model, we test for asymmetric cointegration both when $\tau$ is set to zero and when it is endogenously determined within the M-TAR framework. The interpretation of the TAR and M-TAR models, however, differs. The TAR model tests if the deviation from the long-run equilibrium is persistent assuming equal magnitudes of positive and negative shocks, whereby the M-TAR model tests if the deviation from the long-run equilibrium is persistent irrespective of the magnitude of the disequilibrium.

If asymmetric cointegration is present, the ECM in Eq. (3) can be rewritten as the following TAR model:

$$
\begin{aligned}
& \Delta \mathrm{rr}_{t}=\eta+\gamma_{1} \Delta \operatorname{mpr}_{t}+\sum_{i=1}^{n} \gamma_{i} \Delta \operatorname{mpr}_{t-i}+\delta_{1} \Delta X_{t}+\sum_{k=1}^{m} \delta_{k} \Delta X_{t-k}+I_{t} \rho_{1, r r} u_{t-1} \\
& +\left(1-I_{t}\right) \rho_{2, r r} u_{t-1}+\varepsilon_{t},
\end{aligned}
$$

or the following M-TAR model:

\footnotetext{
${ }_{13}$ Note that the necessary conditions for convergence are for the parameters $\rho_{\mathrm{i}}$ to be negative.
} 


$$
\begin{aligned}
\Delta \mathrm{rr}_{t}= & \eta+\gamma_{1} \Delta \operatorname{mpr}_{t}+\sum_{i=1}^{n} \gamma_{i} \Delta \operatorname{mpr}_{t-i}+\delta_{1} \Delta X_{t}+\sum_{k=1}^{m} \delta_{k} \Delta X_{t-k}+M_{t} \rho_{1, r r} u_{t-1}+(1 \\
& \left.-M_{t}\right) \rho_{2, r r} u_{t-1}+\varepsilon_{t}
\end{aligned}
$$

where $\rho_{1, \text { rr }}$ and $\rho_{2, \text { rr }}$ are the asymmetric speed of adjustment parameters.

\section{Results}

We first present the baseline results for the interest rate pass-through. Then, we present the results accounting for the existence of asymmetries. Finally, we simulate the impact of a change in the monetary policy rate on retail rates.

\subsection{Baseline}

We test for unit root and cointegration. ${ }^{14}$ The results of the ADF test on the levels suggest that the null hypothesis of unit root presence cannot be rejected at five percent significance level for all series, with the exception of the weighted average deposit rate. However, as the evidence of stationarity is not compelling, we proceed to test stationarity for first differences. After first-differencing, the null hypothesis of unit root presence is safely rejected for all series. The Engle-Granger test's null hypothesis of no cointegration is rejected for all series combinations except the government bond rates, suggesting that the monetary policy rate shares a long-run relationship only with the retail rates.

The results for the estimation of the error correction model for retail rates are reported in Table 2. The estimation of Eq. (1) reveals that the pass-through to deposit rates is complete, as the long-run coefficient ranges between 1.0 and 1.1. Similarly, the pass-through to lending rates is complete, with the long-run coefficient ranging from 1.0 to 1.2. To confirm the statistical validity of the finding of complete pass-through, we employ a Wald test with the null hypothesis of the long-run pass-through coefficient being different from one. In all cases, we cannot reject the null hypothesis.

Other explanatory variables turn out significant. An increase in the EMBI spread is unequivocally reflected in higher deposit and lending rates. The effect is robust across maturities and lending categories. An increase in the reserve requirement coefficient is found to have a positive effect on most of the lending rates, consistent with a reduction of liquidity. Changes in the NPL ratio are not significantly associated with retail rates. The exchange rate turns out significant only for the specification of lending rates and personal consumption, suggesting that these increase in response to depreciation. Finally, we find some evidence of lower lending rates owing to heightened advanced economies' volatility risk, proxied by the VIX. However, the effect is relatively small and not robust across maturities.

\footnotetext{
14 See Appendix I for the test results.
} 


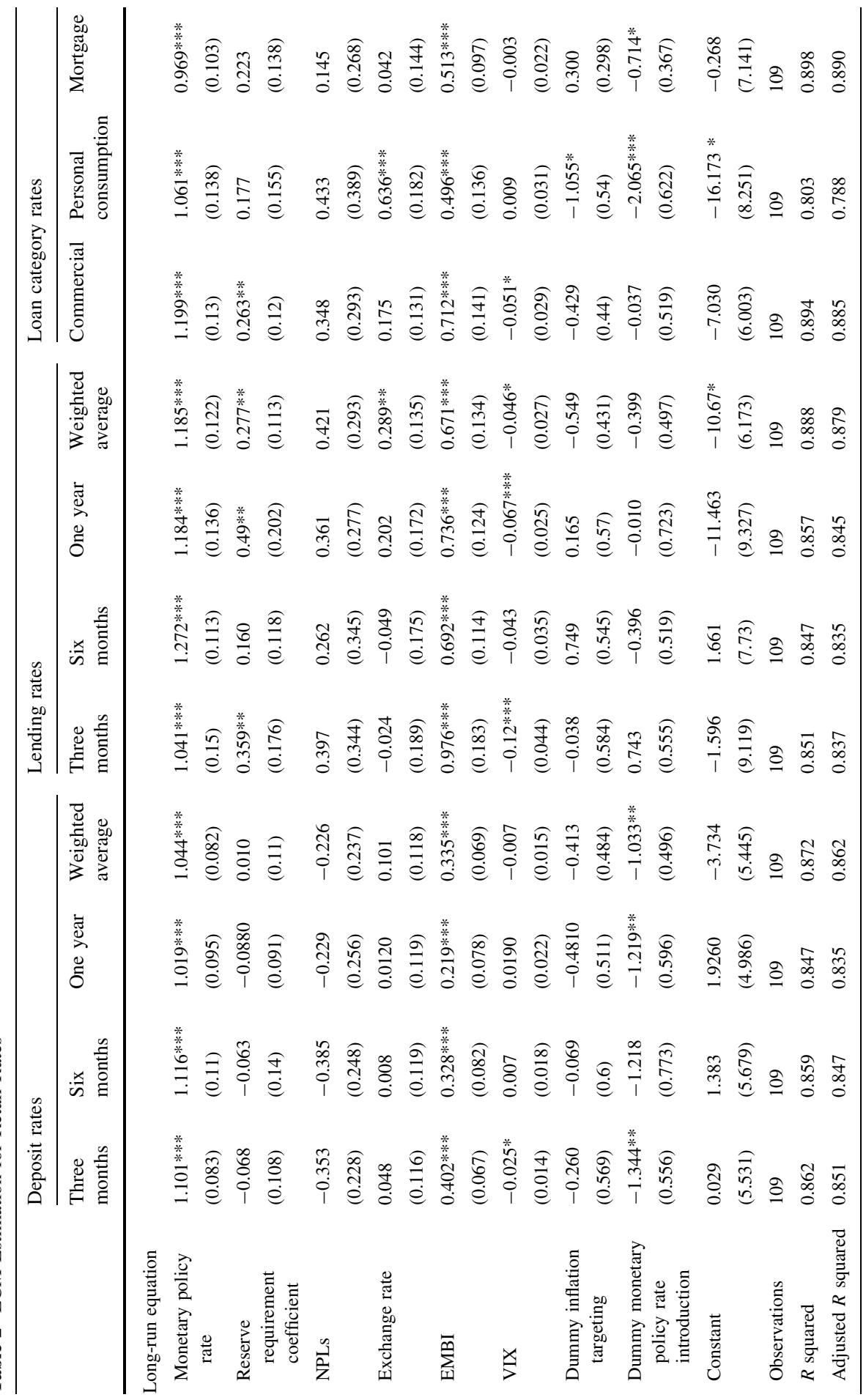




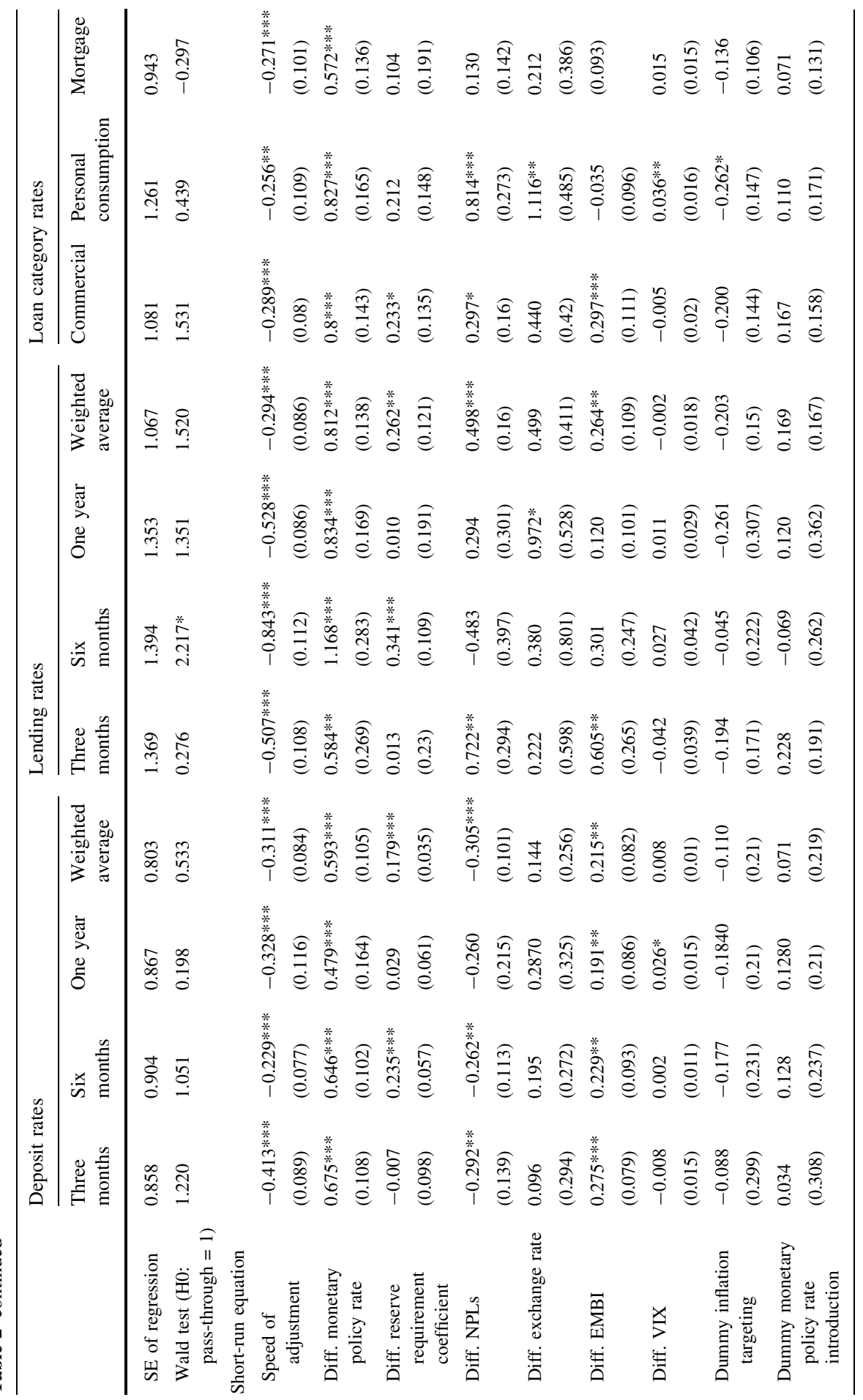




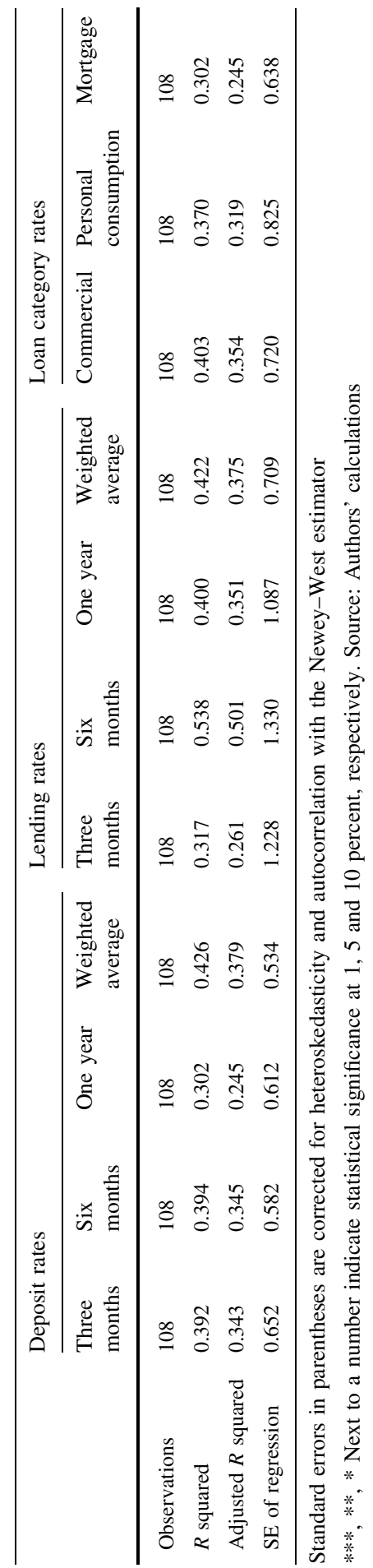


The estimation of Eq. (3) provides information about the short-run effect on retail rates. The short-run effect of one percentage point increase in the change of the monetary policy rate on the change of deposit rates ranges between 0.5 and 0.7 percentage points. In other words, 50 to $70 \%$ of the pass-through is transmitted to deposit rates within the same month. The short-run impact on the change in lending rates ranges between 0.6 and 0.8 percentage points, with the exception of the shortrun impact for the 6-month lending rate, which is 1.2 percentage points. The latter is abnormally high compared to other maturities and the reason may lie with the idiosyncratic movements in the 6-month lending rate, therefore results should be taken with caution. ${ }^{15}$ The only maturity for which the short-run impact on the lending rate is lower than the one on the deposit rate is the 3-month one, implying a decrease in the spread in the short-run.

The speed of adjustment is higher for lending rates. In general, deviations from the long-run equilibrium are more quickly corrected in the case of lending rates as the relative speed of adjustment ranges between -0.3 and -0.8 , compared to a coefficient range between -0.2 and -0.4 for deposit rates.

Other explanatory variables present results generally consistent with the longterm equation estimations. Changes in the EMBI spread are associated with increases in deposit rates and some of the lending rates. Changes in the reserve requirement also increase deposit and lending rates, however, these effects are not robust across maturities and are not significant for lending categories. Somewhat different from the results of the long-term estimations, a positive change in the NPL ratio is associated with a fall in deposit rates and with increases in lending rates. While this finding is not robust for all rates, it possibly underscores the banks' need to compensate for the fall in profitability that occurs when more loans become nonperforming and losses are provisioned. Finally, changes in the VIX index turn out to be significant only in raising the change in the personal consumption rate and by a minor amount.

Table 3 presents the results of the ADL estimation in Eq. (2) for the government bond rates. ${ }^{16}$ As expected, changes in the monetary policy rate only affect changes in the rates of domestically issued bonds. More specifically, a change in the monetary policy rate by one percentage point is associated with a short-run impact on the change of domestically issued bond rates by $0.5-0.6$ percentage points, depending on the maturity of the instrument. Using the coefficient of the lagged differenced dependent variable, we can retrieve the long-run coefficient which ranges between 0.8 and 0.9 percentage points. Thus, the pass-through in this case seems less than complete.

\footnotetext{
15 Alternative estimations using dummy variables for September and October of 2009 present a short-run coefficient of 0.8. However, we opt to drop dummies in the baseline specifications as we have no clear reasons for including them.

${ }^{16}$ Given the short sample and the little variation in the monetary policy rate over it, we also estimate the ADL model replacing the monetary policy rate with the interbank rate. The results are similar and available from the authors upon request.
} 
Table 3 ADL model estimation for government bonds

\begin{tabular}{|c|c|c|c|c|}
\hline & \multicolumn{3}{|l|}{ Domestic } & \multirow{2}{*}{$\begin{array}{l}\text { External } \\
10 \text { years }\end{array}$} \\
\hline & Five years & 7 years & 10 years & \\
\hline \multirow[t]{2}{*}{ Diff. monetary policy rate } & $0.567 * * *$ & $0.48 * * *$ & $0.447 * * *$ & -0.009 \\
\hline & $(0.168)$ & $(0.109)$ & $(0.138)$ & $(0.073)$ \\
\hline \multirow[t]{2}{*}{ Lag diff. monetary policy rate } & $0.554 * * *$ & $0.759 * * *$ & $0.463 * *$ & $-0.104 *$ \\
\hline & $(0.184)$ & $(0.181)$ & $(0.195)$ & $(0.06)$ \\
\hline \multirow[t]{2}{*}{ Lag diff. dependent variable } & $-0.493 * * *$ & $-0.325^{* *}$ & -0.210 & $-0.104 *$ \\
\hline & $(0.136)$ & $(0.137)$ & $(0.158)$ & $(0.06)$ \\
\hline \multirow[t]{2}{*}{ Diff. reserve requirement coefficient } & 0.040 & 0.073 & $-0.125 * *$ & -0.010 \\
\hline & $(0.719)$ & $(0.047)$ & $(0.057)$ & $(0.023)$ \\
\hline \multirow[t]{2}{*}{ Diff. EMBI } & $0.945^{* *}$ & 0.680 & 0.473 & $1.018 * * *$ \\
\hline & $(0.44)$ & $(0.459)$ & $(0.347)$ & $(0.08)$ \\
\hline \multirow[t]{2}{*}{ Diff. VIX } & $-0.074^{*}$ & -0.019 & $-0.043^{* *}$ & $-0.026^{* * *}$ \\
\hline & $(0.04)$ & $(0.034)$ & $(0.02)$ & $(0.007)$ \\
\hline \multirow[t]{2}{*}{ Dummy inflation targeting } & -0.356 & 0.064 & -0.086 & 0.035 \\
\hline & $(0.289)$ & $(0.273)$ & $(0.163)$ & $(0.076)$ \\
\hline \multirow[t]{2}{*}{ Dummy monetary policy rate introduction } & 0.298 & 0.018 & 0.167 & 0.031 \\
\hline & $(0.232)$ & $(0.183)$ & $(0.181)$ & $(0.058)$ \\
\hline \multirow[t]{2}{*}{ Constant } & -0.120 & -0.197 & -0.180 & -0.075 \\
\hline & $(0.198)$ & $(0.212)$ & $(0.118)$ & $(0.062)$ \\
\hline Observations & 54 & 41 & 57 & 61 \\
\hline$R$ squared & 0.398 & 0.341 & 0.255 & 0.682 \\
\hline Adjusted $R$ squared & 0.291 & 0.176 & 0.131 & 0.633 \\
\hline SE of regression & 0.867 & 0.593 & 0.565 & 0.186 \\
\hline
\end{tabular}

Standard errors in parentheses are corrected for heteroskedasticity and autocorrelation with the NeweyWest estimator

$* * *, * *, *$ Next to a number indicate statistical significance at 1,5 and 10 percent, respectively. Source: Authors' calculations

\subsection{Asymmetries}

We employ the TAR and M-TAR tests to explore asymmetric cointegration between the monetary policy rate and all retail rates. ${ }^{17}$ As a first step, we set the threshold to zero. In the case of the TAR test, the null hypothesis of symmetric cointegration cannot be rejected. The results are similar in the case of the M-TAR test, as we cannot find evidence of asymmetric cointegration. As a second step, we let the TAR and M-TAR threshold to be endogenously determined. When employing the TAR test, we find evidence of asymmetric cointegration for the weighted average deposit rate, 3-month, 6-month, and 1 -year lending rates, and the mortgage lending rate. The M-TAR test finds even stronger evidence of asymmetric cointegration, as it rejects the null hypothesis of symmetric cointegration for all series, except the 6-month lending rate.

\footnotetext{
17 See Appendix I for the test results.
} 


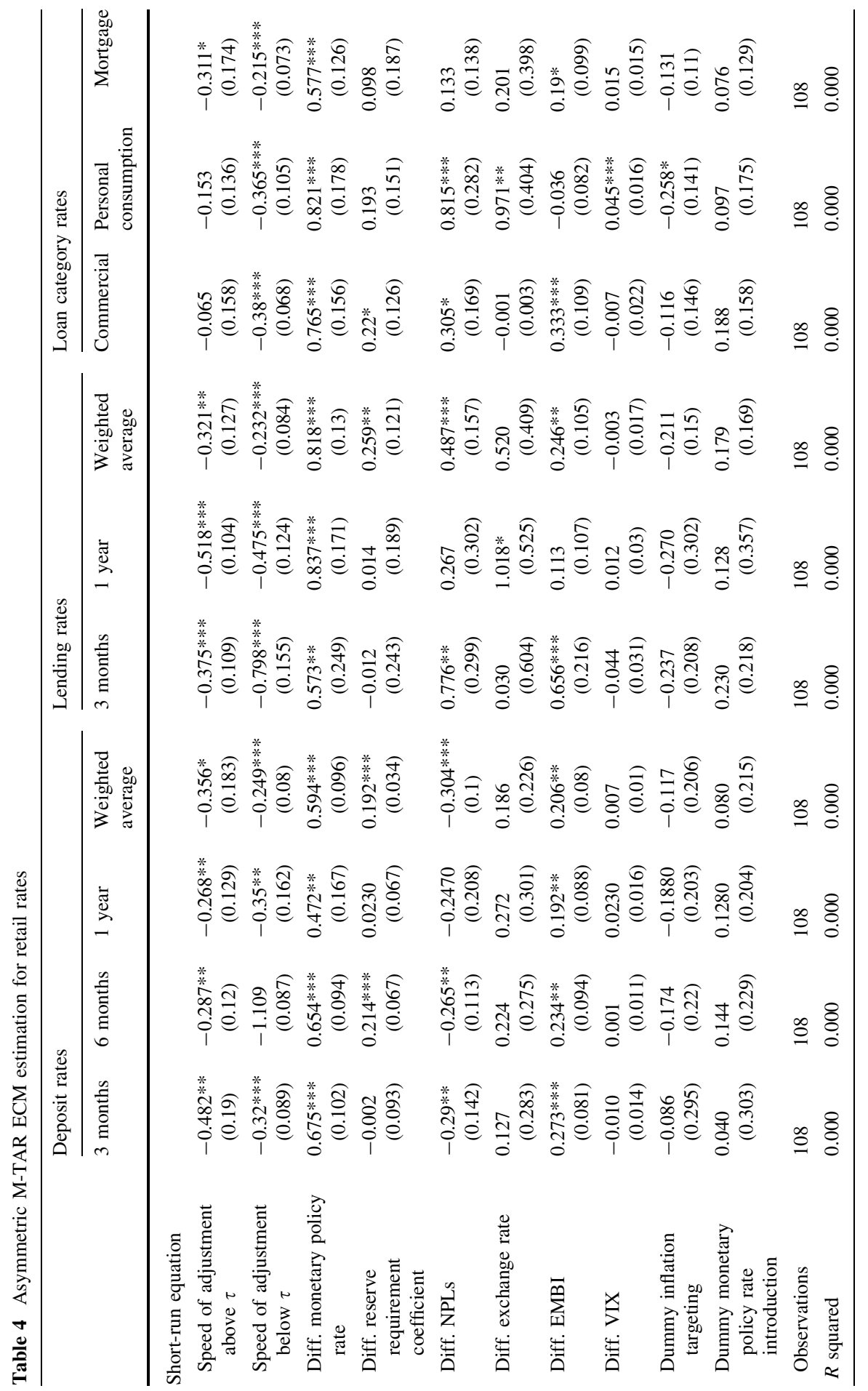




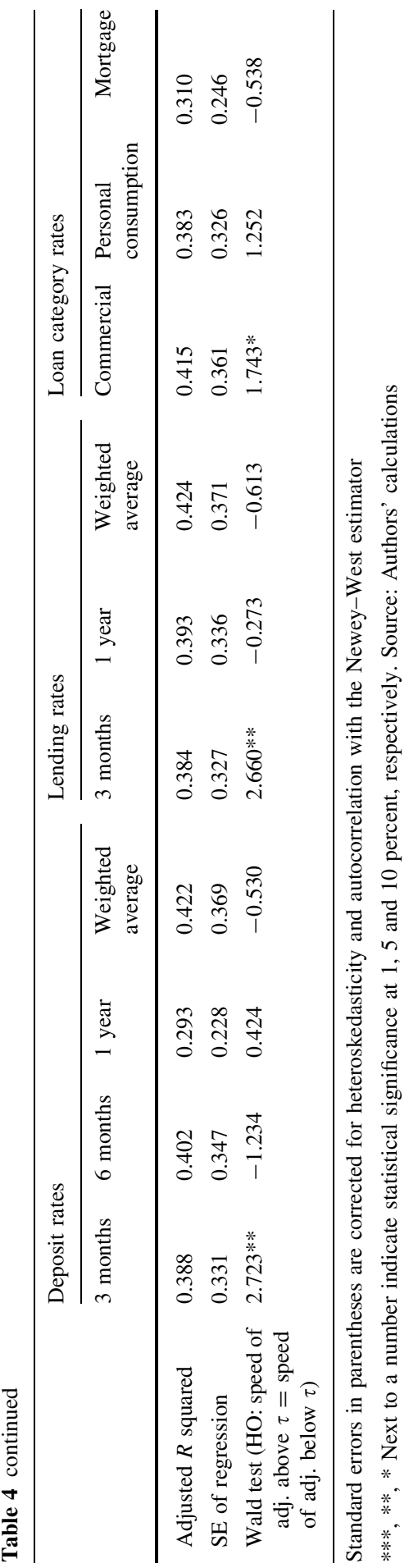



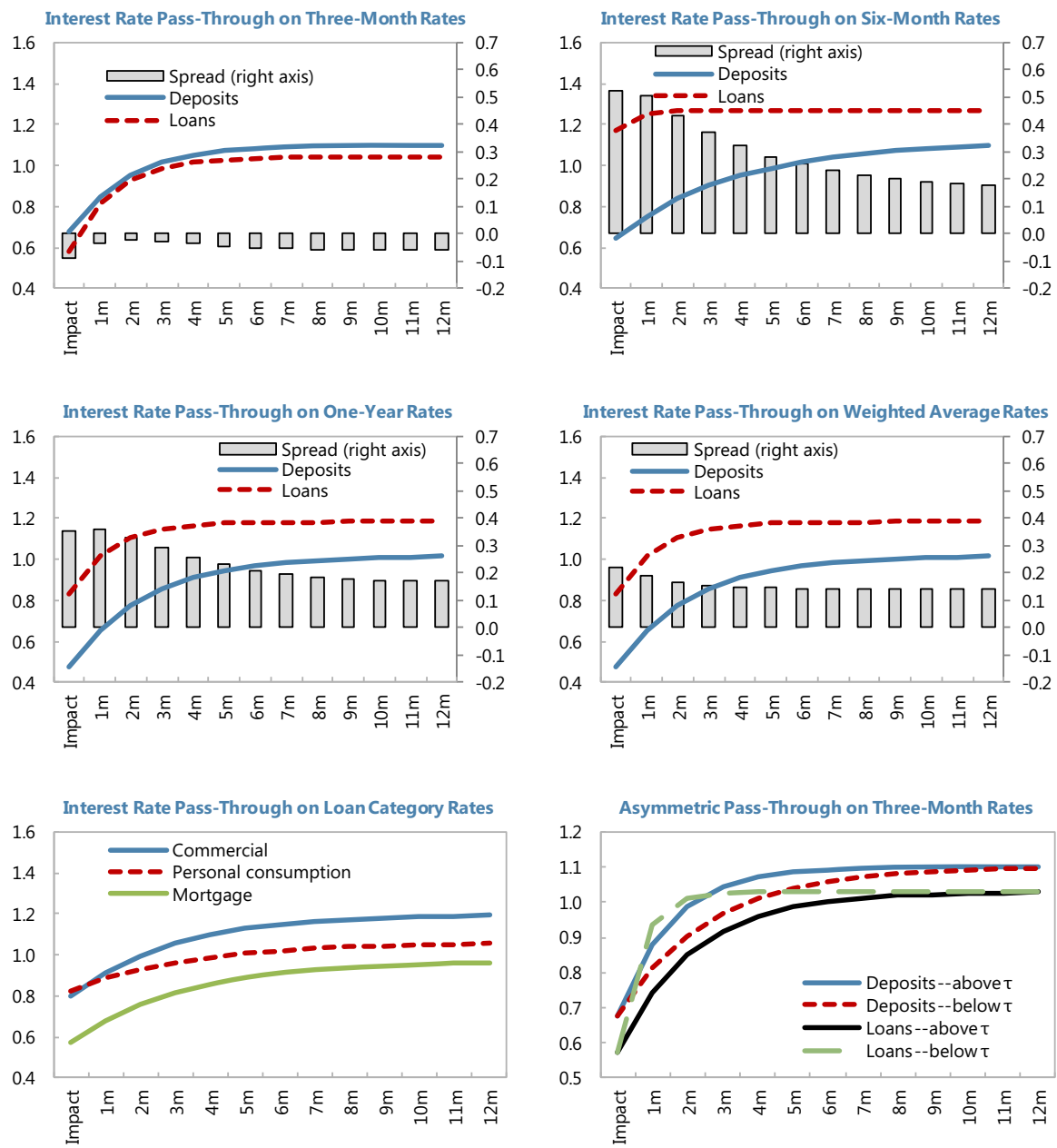

Fig. 1 Timing of one percentage point change in the monetary policy rate (percentage points). Notes: Deviations above $\tau$ correspond to monetary policy rate cuts, while deviations below $\tau$ correspond to monetary policy rate hikes. Source: Authors' calculations

The results of the M-TAR cointegration tests with the endogenously determined threshold warrant the use of the asymmetric ECM. Table 4 reports the results of the estimation of Eq. (9) for all series but the 6-month lending rate, for which the hypothesis of symmetric cointegration cannot be rejected. Our attention falls on the speed of adjustment above and below the threshold. If the retail rate is above its equilibrium value after a decrease in the monetary policy rate, then the retail rate will adjust by the coefficient of the speed of adjustment above $\tau$ in every period. Conversely, if the retail rate is below its equilibrium value after an increase in the monetary policy rate, then the lending rate will adjust by the coefficient of the speed of adjustment below $\tau$ in every period. 
We find evidence of significant asymmetric adjustment for the 3-month rates. In particular, we employ a Wald test with a null hypothesis for which the speed of adjustment above $\tau$ is equal to the speed of adjustment below $\tau$. Our results suggest that the speed of adjustment for the 3-month deposit rate is higher when the monetary policy rate falls. Conversely, the speed of adjustment for the 3-month lending rate is higher when monetary policy rate increases. More specifically, the speed of adjustment for positive deviations is 1.5 times the one for negative deviations in the case of deposit rates, suggesting that negative deviations are more persistent, whereas the speed of adjustment for negative deviations is two times the one for positive deviations in the case of lending rates, suggesting that positive deviations are more persistent.

For rates at higher maturities the two speeds of adjustment coefficients are not significantly different from each other. However, short maturities provide a better measure as loans are typically not collateralized and this allows isolating the balance sheet channel (Mishkin 1995). In other words, the pass-through does not depend on market price variations that influence the value of collateral. This reinforces the evidence of the results on 3-month rates.

\subsection{Simulation}

To evaluate the effect of an exogenous monetary policy shock, we conduct a simulation exercise to generate time paths for retail rates. The policy experiment consists of a policy tightening corresponding to an increase by one percentage point in the monetary policy rate, starting from a situation in which the system is in equilibrium and simulating the adjustment of the retail rates over the following year. Figure 1 presents the symmetric adjustment path for all retail rates, as well as the asymmetric adjustment path for the 3 -month rates. ${ }^{18}$

While the symmetric adjustment dynamics for different maturities are slightly different, they all imply changes in spreads between 0.0 and 0.2 percentage points when the adjustment is completed. On impact, an increase in the monetary policy rate generates a negative spread of about 0.1 percentage points only for the 3 -month rates. The spread, however, halves over time. As the simulated adjustment is symmetric by construction, any monetary policy easing implies a reduction in banks' profitability by the same amount during the first month.

Personal consumption and commercial loans are the fastest in incorporating monetary policy changes. However, given the lower pass-through for the former, the adjustment completes earlier despite a lower speed of adjustment. Mortgage loans, possibly because of the higher frequency at which they are taken, display a smaller short-run effect from the monetary policy rate change, but their speed of convergence to long-run equilibrium is similar to the one of commercial loans.

Finally, we present the asymmetric adjustment path for the 3-month rates. By construction, the short- and long-run impact is the same regardless of whether the

\footnotetext{
${ }_{18}$ The law of motion for the retail rates is defined as, $\operatorname{rr}_{t}=\gamma_{1}+\rho\left(\beta_{1}-\gamma_{1}\right)$ where $\gamma_{1}$ is the short-run impact of the monetary policy rate from Eq. (3), $\rho$ is the speed of adjustment from Eq. (3), and $\beta_{1}$ is the lont-run impact of the monetary policy from Eq. (3). In the case of the asymmetric adjustment, $\rho$ is alternatively $\rho_{1}$ or $\rho_{2}$ from Eq. (8).
} 
shock generates a deviation above or below the threshold. However, the different speeds of adjustments imply that deviations above the threshold (i.e., monetary policy rate cuts) are corrected in a much faster fashion than deviations below it (i.e., monetary policy rate hikes) for deposit rates, while the opposite is true for lending rates.

\section{Conclusions}

This paper investigates the interest rate pass-through of monetary policy rates to retail rates in the Dominican Republic. Based on a recent 10-year monthly sample from 2006 to 2015, we estimate the interest rate pass-through for deposit and lending rates at different maturities and for different loan category rates. Also, we explore the costs associated with changes in the monetary policy stance by estimating the interest rate pass-through to government bond rates. Finally, we investigate if the speed of the monetary transmission mechanism is conditional on whether the monetary policy becomes more contractionary or expansionary, and we simulate its impact on the retail rates.

We find that while the pass-through to deposit and lending rates is complete, confirming the effectiveness of the monetary policy transmission mechanism. Government domestic bond rates also react to monetary policy changes. Moreover, our results reveal that the pass-through to lending rates is generally faster than to deposit rates. Finally, we find some evidence of asymmetric adjustment as shortterm deposit rates respond faster to monetary policy rate cuts than hikes, and shortterm lending rates respond faster to monetary policy rate hikes than cuts.

The theoretical literature explains asymmetric adjustment in the speed of adjustment of retail rates with the collusive market hypothesis. In particular, the bargaining power of banks could explain why the lending rates exhibit downward rigidity to a monetary policy rate cut and upward flexibility to a monetary policy rate hike. From a policy perspective, measures to reduce bank concentration and boost competition in the financial system could be instrumental in enhancing the effectiveness of monetary policy transmission mechanism by reducing asymmetries in the adjustment of retail rates.

Open Access This article is distributed under the terms of the Creative Commons Attribution 4.0 International License (http://creativecommons.org/licenses/by/4.0/), which permits unrestricted use, distribution, and reproduction in any medium, provided you give appropriate credit to the original author(s) and the source, provide a link to the Creative Commons license, and indicate if changes were made.

\section{Appendix I. Unit root and cointegration test results}

See Tables 5, 6, 7 and 8 . 
Table 5 Unit root, ADF test

\begin{tabular}{|c|c|c|c|c|c|c|}
\hline & \multicolumn{3}{|l|}{ Levels } & \multicolumn{3}{|c|}{ First differences } \\
\hline & $\begin{array}{l}\text { No } \\
\text { intercept, } \\
\text { no trend }\end{array}$ & $\begin{array}{l}\text { Intercept, } \\
\text { no trend }\end{array}$ & $\begin{array}{l}\text { Intercept, } \\
\text { trend }\end{array}$ & $\begin{array}{l}\text { No } \\
\text { intercept, no } \\
\text { trend }\end{array}$ & $\begin{array}{l}\text { Intercept, } \\
\text { no trend }\end{array}$ & $\begin{array}{l}\text { Intercept, } \\
\text { trend }\end{array}$ \\
\hline $\begin{array}{l}\text { Monetary policy } \\
\text { rate }\end{array}$ & -1.490 & -2.266 & -2.399 & $-8.510^{* * *}$ & $-8.534 * * *$ & $-8.543 * * *$ \\
\hline $\begin{array}{l}\text { Three-month } \\
\text { deposit rate }\end{array}$ & -1.285 & $-2.910^{*}$ & -2.999 & $-7.112^{* * *}$ & $-7.104 * * *$ & $-7.074 * * *$ \\
\hline $\begin{array}{l}\text { Six-month deposit } \\
\text { rate }\end{array}$ & -1.203 & $-3.212^{* *}$ & $-3.328 *$ & $-5.567 * * *$ & $-5.558 * * *$ & $-5.541 * * *$ \\
\hline $\begin{array}{l}\text { One-year deposit } \\
\text { rate }\end{array}$ & -1.331 & $-3.114 * *$ & $-3.275^{*}$ & $-6.546^{* * *}$ & $-6.540^{* * * *}$ & $-6.526^{* * *}$ \\
\hline $\begin{array}{l}\text { Weighted average } \\
\text { deposit rate }\end{array}$ & -1.355 & $-3.537 * *$ & $-3.696 * *$ & $-5.214^{* * *} *$ & $-5.207 * * *$ & $-5.192 * * *$ \\
\hline $\begin{array}{l}\text { Three-month } \\
\text { lending rate }\end{array}$ & -1.056 & -2.516 & -2.712 & $-11.970 * * *$ & $-11.938 * * *$ & $-11.907 * * *$ \\
\hline $\begin{array}{l}\text { Six-month lending } \\
\text { rate }\end{array}$ & -1.079 & -2.242 & -2.466 & $-15.009 * * *$ & $-14.971 * * *$ & $-14.907 * * *$ \\
\hline $\begin{array}{l}\text { One-year lending } \\
\text { rate }\end{array}$ & -1.119 & -2.442 & -2.579 & $-12.273 * * *$ & $-12.238^{* * *} *$ & $-12.170 * * *$ \\
\hline $\begin{array}{l}\text { Weighted average } \\
\text { lending rate }\end{array}$ & -0.990 & -2.314 & -2.494 & $-7.407 * * *$ & $-7.398 * * *$ & $-7.360 * * *$ \\
\hline $\begin{array}{l}\text { Commercial } \\
\text { lending rate }\end{array}$ & -0.968 & -2.231 & -2.369 & $-7.576^{* * * *}$ & $-7.561 * * *$ & $-7.531 * * *$ \\
\hline $\begin{array}{l}\text { Personal } \\
\text { consumption } \\
\text { lending rate }\end{array}$ & -0.833 & -2.468 & -2.560 & $-7.804 * * *$ & $-7.792^{* * *}$ & $-7.746^{* * *}$ \\
\hline $\begin{array}{l}\text { Mortgage lending } \\
\text { rate }\end{array}$ & -1.175 & -2.286 & -2.790 & $-6.050 * * *$ & $-6.063 * * *$ & $-6.014 * * *$ \\
\hline $\begin{array}{l}\text { Five-year } \\
\text { government } \\
\text { domestic bond }\end{array}$ & $-1.962 * *$ & $-3.113^{* *}$ & $-3.414^{*}$ & $-12.655^{* * *}$ & $-13.009 * * *$ & $-12.787 * * *$ \\
\hline $\begin{array}{l}\text { Seven-year } \\
\text { government } \\
\text { domestic bond }\end{array}$ & $-2.002 * *$ & -2.182 & -2.577 & $-6.808 * * *$ & $-7.053 * * *$ & $-6.966^{* * *}$ \\
\hline $\begin{array}{l}\text { Ten-year } \\
\text { government } \\
\text { domestic bond }\end{array}$ & -1.458 & -0.806 & -2.000 & $-7.556^{* * *}$ & $-7.696^{* * *}$ & $-7.643 * * *$ \\
\hline $\begin{array}{l}\text { Ten-year } \\
\text { government } \\
\text { external bond }\end{array}$ & -1.416 & -1.559 & -2.024 & $-6.451 * * *$ & $-6.534 * * *$ & $-6.497 * * *$ \\
\hline
\end{tabular}

The null hypothesis is that the series has a unit root. The lagged differences are included in the specifications to obtain white noise residuals The Schwarz information criterion is used to select the optimal lag length

$* * *, * *$, Next to a number indicate statistical significance at 1, 5 and 10 percent, respectively Source: Authors' calculations 
Table 6 Cointegration, EngleGranger test

The null hypothesis is that the series do not have a

cointegration relationship. The Schwarz information criterion is used to select the optimal lag length. The critical values are from MacKinnon (1991)

$* * *, * *, *$ Next to a number indicate statistical significance at 1,5 and 10 percent, respectively. Source: Authors' calculations

\begin{tabular}{lc}
\hline 3-month deposit rate & $-5.489 * * *$ \\
6-month deposit rate & $-5.531^{* * *}$ \\
1-year deposit rate & $-4.928^{* *}$ \\
Weighted average deposit rate & $-6.185^{* *}$ \\
3-month lending rate & $-6.187 * * *$ \\
6-month lending rate & $-8.774 * * *$ \\
1-year lending rate & $-6.806 * * *$ \\
Weighted average lending rate & $-6.741^{* * *}$ \\
Commercial lending rate & $-6.373^{* * *}$ \\
Personal consumption lending rate & $-6.158^{* * *}$ \\
Mortgage lending rate & $-7.324 * * *$ \\
5-year government domestic bond & -3.640 \\
7-year government domestic bond & -3.224 \\
10-year government domestic bond & -3.094 \\
10-year government external bond & -3.040 \\
\hline
\end{tabular}

Table 7 Cointegration, TAR and M-TAR tests with threshold set to zero

\begin{tabular}{|c|c|c|c|c|}
\hline & \multicolumn{2}{|l|}{ TAR } & \multicolumn{2}{|l|}{ M-TAR } \\
\hline & $\Phi\left(\rho_{1}=\rho_{2}=0\right)$ & $F\left(\rho_{1}=\rho_{2}\right)$ & $\Phi(M)\left(\rho_{1}=\rho_{2}=0\right)$ & $F(M)\left(\rho_{1}=\rho_{2}\right)$ \\
\hline 3-month deposit rate & $14.588 * * *$ & 0.032 & $14.648 * * *$ & 0.124 \\
\hline 6-month deposit rate & $15.649 * * *$ & 0.062 & $16.393 * * *$ & 1.202 \\
\hline 1-year deposit rate & 3.406 & 0.111 & 3.606 & 0.480 \\
\hline $\begin{array}{l}\text { Weighted average } \\
\text { deposit rate }\end{array}$ & $18.225 * * *$ & 0.617 & $18.723 * * *$ & 1.355 \\
\hline 3 -month lending rate & $5.116^{*}$ & 0.481 & $6.975 * *$ & 3.823 \\
\hline 6-month lending rate & $8.884 * *$ & 0.996 & $16.393 * * *$ & 1.202 \\
\hline 1-year lending rate & $20.237 * * *$ & 0.141 & 3.605 & 0.480 \\
\hline $\begin{array}{l}\text { Weighted average } \\
\text { lending rate }\end{array}$ & $17.890 * * *$ & 0.015 & $18.055^{* * *}$ & 0.260 \\
\hline Commercial lending rate & $19.294 * * *$ & 0.048 & $19.418 * * *$ & 0.228 \\
\hline $\begin{array}{l}\text { Personal consumption } \\
\text { lending rate }\end{array}$ & 2.211 & 0.018 & 2.276 & 0.143 \\
\hline Mortgage lending rate & $17.346 * * *$ & $1.393^{*}$ & $18.007 * * *$ & 2.392 \\
\hline
\end{tabular}

The null hypothesis of the test statistic $\Phi$ is that the series do not have a cointegration relationship, and the null hypothesis of the test statistic $F$ is that the series have symmetric cointegration relationships. The critical values are generated via Monte Carlo simulations. Source: Authors' calculations $* * *, * *, *$ Next to a number indicate statistical significance at 1,5 
Table 8 Cointegration, TAR and M-TAR tests with endogenously determined threshold

\begin{tabular}{|c|c|c|c|c|c|c|}
\hline & \multicolumn{3}{|l|}{ TAR } & \multicolumn{3}{|l|}{ M-TAR } \\
\hline & $\begin{array}{l}\Phi \\
\left(\rho_{1}=\rho_{2}=0\right)\end{array}$ & $\begin{array}{l}F \\
\left(\rho_{1}=\rho_{2}\right)\end{array}$ & $\tau$ & $\begin{array}{l}\Phi \\
\left(\rho_{1}=\rho_{2}=0\right)\end{array}$ & $\begin{array}{l}F \\
\left(\rho_{1}=\rho_{2}\right)\end{array}$ & $\tau$ \\
\hline Three-month deposit rate & $15.165^{* * *}$ & 0.929 & -0.613 & $16.390 * * *$ & $2.835 * * *$ & 0.732 \\
\hline Six-month deposit rate & $15.848 * * *$ & 0.367 & -0.342 & $17.084 * * *$ & $2.260 * * *$ & -0.316 \\
\hline One-year deposit rate & 3.649 & 0.543 & -0.727 & $5.338 *$ & $3.694 * * *$ & 0.089 \\
\hline $\begin{array}{l}\text { Weighted average } \\
\text { deposit rate }\end{array}$ & $19.058 * * *$ & $1.851 * * *$ & -0.525 & $19.848 * * *$ & $3.022 * * *$ & 0.341 \\
\hline $\begin{array}{l}\text { Three-month lending } \\
\text { rate }\end{array}$ & $6.488^{* *}$ & $2.948 * * *$ & -1.292 & $7.932 * *$ & $5.543 * * *$ & -0.402 \\
\hline Six-month lending rate & $9.334 * * *$ & $1.752 * * *$ & 0.505 & $8.806^{* *}$ & 0.865 & 1.417 \\
\hline One-year lending rate & $21.470 * * *$ & $1.908 * * *$ & 1.188 & $23.321 * * *$ & $4.562 * * *$ & 0.827 \\
\hline $\begin{array}{l}\text { Weighted average } \\
\text { lending rate }\end{array}$ & $18.243 * * *$ & 0.538 & 0.853 & $19.547 * * *$ & $2.469 * * *$ & -0.577 \\
\hline Commercial lending rate & $19.916^{* * *}$ & 0.951 & -0.889 & $20.300 * * *$ & $1.508 * *$ & -0.73 \\
\hline $\begin{array}{l}\text { Personal consumption } \\
\text { lending rate }\end{array}$ & 2.295 & 0.178 & -1.039 & 4.136 & $3.682 * * *$ & 0.082 \\
\hline Mortgage lending rate & $18.416^{* * * *}$ & $3.012 * * *$ & -0.583 & $19.092 * * *$ & $4.033 * * *$ & -0.024 \\
\hline
\end{tabular}

The null hypothesis of the test statistic $\Phi$ is that the series do not have a cointegration relationship, and the null hypothesis of the test statistic $F$ is that the series have symmetric cointegration relationships. $\tau$ is the estimated threshold. The critical values are generated via Monte Carlo simulations. Source: Authors' calculations

$* * *, * *, *$ Next next to a number indicate statistical significance at 1,5 and 10 percent, respectively

\section{References}

Andújar J (2012) El Efecto Traspaso de las Tasas de Interés en República Dominicana. Banco Central de la Republica Dominicana, Serie de Estudios Económicos, vol. 4

Andújar J (2014) La transición de la República Dominicana a metas de inflación. Revista Dominicana de Economía 5:99-120

Aristy Escuder J (2014) The impact of policy interest rate on loan and deposit interest rates. Ciencia y Sociedad 39(4):683-702

Banco Central de la Republica Dominicana (2015). Informe de Politica Monetaria, Mayo

Becker R, Osborn DR, Yildirim D (2012) A threshold cointegration analysis of interest rate pass-through to UK mortgage rates. Econ Model 29:2504-2513

Berger AN, Udell GF (1992) Some evidence on the empirical significance of credit rationing. J Politi Econ 25:291-299

Bernanke B, Gertler M, Gilchrist S (1996) The financial accelerator and the flight to quality. Rev Econ Stat 78(1):1-15

Carner M, Hansen BH (1998) Threshold autoregression with a near unit root. Working Paper, University of Wisconsin, Department of Economics

Chan KS (1993) Consistency and limiting distribution of the least squares estimator of a threshold autoregressive model. Ann Stat 21:520-533

De Bondt G (2002) Retail bank interest rate pass-through: new evidence at the Euro area level. Working paper series, vol. 136, European Central Bank, Frankfurt, Germany

De Bondt G (2005) Interest rate pass-through: empirical results for the Euro area. Germany Econ Rev 6(1):37-78 
De Bondt G, Mojon B, Valla N (2003) Term structure and the sluggishness of retail bank rates in Euro area countries. Mimeo, European Central Bank

Doornik J, Hendry DF (1994) An interactive econometric modelling system. International Thompson Publishing, London

Égert B, Macdonald R (2009) Monetary transmission mechanism in central and eastern Europe: surveying the surveyable. J Econ Survey 23(2):277-327

Égert B, Crespo-Cuaresma J, Reininger T (2007) Interest rate pass-through in central and eastern Europe: reborn from ashes merely to pass-away. J Policy Model 29:209-225

Enders W, Granger CWJ (1998) Unit root tests and asymmetric adjustment with an example using the term structure of interest rates. J Bus Econ Stat 16:304-311

Enders W, Siklos PL (2001) Cointegration and threshold adjustment. J Bus Econ Stat 19(2):166-176

Fried J, Howitt P (1980) credit rationing and implicit contract theory. J Money Credit Bank 12:471-487

Gerali A, Neri S, Sessa L, Signoretti FM (2010) Credit and banking in a DSGE model of the Euro area. J Money Credit Bank 42(1):107-141

Gertler M, Karadi P (2011) A model of unconventional monetary policy. J Int Econ 58:17-34

González Pantaleón JA (2010) Traspaso de la Política Monetaria a las Tasas de Interés de Mercado y sus Efectos en el Sector Real. Evidencia para República Dominicana. Nueva Literatura Económica Dominicana

Hamilton JD (1994) Time series analysis. Princeton University Press, Princeton

Hannan TH, Berger AN (1991) The rigidity of prices: evidence from the banking industry. Am Econ Rev 81(4):938-945

Hendry DF, Nielsen B (2007) econometric modeling: a likelihood approach. Princeton University Press), Princeton

Lowe P, Rohling T (1992) Loan rate riskiness: theory and evidence, Research Discussion Paper. Reserve Bank of Australia, Sydney

Marotta G (2009) Structural breaks in the lending interest rate pass-through and the Euro. Econ Model 26:191-205

Medina Cas S, Frantischek F, Carrion-Menendez A (2011) The policy interest-rate pass-through in Central America. IMF Working Paper 11/240

Mishkin FS (1995) The symposium of the monetary transmission mechanism. J Econ Perspect 9(4):3-10

Rivas R (2011) The pass-through of interest rates: the case of the Dominican Republic. Pontificia Universidad Catolica de Chile, Instituto de Economia

Rotemberg JJ, Saloner G (1987) The relative rigidity of monopoly pricing. Am Econ Rev 77:917-926

Stiglitz JE, Weiss A (1981) Credit rationing in markets with imperfect market information. Am Econ Rev 71:393-410 